\title{
Adoption of Climate Smart Agriculture by Communal Livestock Farmers in South Africa
}

\author{
Lerato Molieleng ${ }^{1, *(\mathbb{D}}$, Pieter Fourie ${ }^{1}$ and Ifeoma Nwafor ${ }^{2}$ \\ 1 Department of Agriculture, Central University of Technology, Free State, Bloemfontein 9300, South Africa; \\ pfourie@cut.ac.za \\ 2 Centre for Applied Food Sustainability and Biotechnology (CAFSaB), Central University of Technology, \\ Free State, Bloemfontein 9300, South Africa; inwafor@cut.ac.za \\ * Correspondence: molielenglerato1@gmail.com; Tel.: +27-(0)83-946-8491
}

Citation: Molieleng, L.; Fourie, P.; Nwafor, I. Adoption of Climate Smar Agriculture by Communal Livestock Farmers in South Africa. Sustainability 2021, 13, 10468. https://doi.org/ $10.3390 /$ su131810468

Academic Editor: Roberto Mancinelli

Received: 18 May 2021

Accepted: 25 June 2021

Published: 21 September 2021

Publisher's Note: MDPI stays neutral with regard to jurisdictional claims in published maps and institutional affiliations.

Copyright: (c) 2021 by the authors. Licensee MDPI, Basel, Switzerland. This article is an open access article distributed under the terms and conditions of the Creative Commons Attribution (CC BY) license (https:// creativecommons.org/licenses/by/ $4.0 /)$.

\begin{abstract}
The importance of adopting modern technology in agriculture, especially in a changing climate, cannot be underestimated in Africa. The aim of this review was to highlight the past and the status quo with regard to the adoption of current farming practices in relation to climate-smart agriculture (CSA) by communal livestock farmers in South Africa. The impact of animal agriculture on climate change was also deliberated. Different internet search engines and databases, like Google Scholar, EBSCO Host, Science Direct, etc., and peer-reviewed articles, books, and government and academic reports were employed to provide information to adequately address the aim. Keywords like "the impact of climate smart agriculture on communal livestock farmers", "communal livestock in South Africa", "communal farming and technology adoption", etc. were used for the search. Various issues pertaining to the impact of animal agriculture on climate change, greenhouse gas (GHG) emissions, and implementing CSA in livestock farming were extensively discussed. The findings indicated that there is limited research on the adoption of CSA by communal livestock farmers in South Africa. The review concluded that strategies to adopt modern technology in communal areas should address the issues to enhance knowledge of farmers and all stakeholders, through increasing awareness, trainings, and skills programs. The government should build local capacity in innovative and affordable water and agricultural solutions, and reliable financial mechanisms should be in place to implement innovative sound technologies in communal areas.
\end{abstract}

Keywords: climate smart agriculture; communal livestock farmers; technology; adoption

\section{Introduction}

Climate change poses serious developmental challenges for Africa, starting from greenhouse gas emissions to the resultant effects of these emissions on agriculture. Therefore, the need for the adoption of climate risk perspectives and a reduction in greenhouse gases is crucial. Since African countries are amongst the most vulnerable to climate change and variability [1], the need to adopt mitigative strategies becomes imperative. The concept of climate-smart agriculture (CSA), which was introduced by the Food and Agriculture Organization (FAO) [2], is aimed at addressing the challenges of climate change and food security. Climate-smart agriculture (CSA) is defined as agriculture that sustainably increases productivity, enhances resilience, and reduces greenhouse gases (GHGs) (mitigation) where possible and enhances the achievement of national food security and development goals [2]. It has been reported that agricultural practices like animal production, forestry, crop farming, aquaculture, and other land-use sectors contribute $24 \%$ of anthropogenic global greenhouse gas emissions [3], hence, this vital concept of CSA.

Communal livestock farming is an agricultural unit in which livestock farmers or villages work together on the same piece of land and run their holdings as joint enterprises. Some of these units operate in state-owned lands, leased land, or privately owned land [4]. This system of farming is the oldest farming approach that is associated with improved 
household farming security and it is still practiced in many rural parts of South Africa. Since more than $75 \%$ of the world's poorest people live in rural areas and 2.5 billion people live on small farms and are entirely dependent on agriculture for their livelihood [4], communal livestock farming then becomes a means to achieving food security.

Climate change knows no size of farming and it affects every citizen that depends on agriculture in South Africa or people living in other parts of the world. Its major impact is visible to the agricultural industry because of its vulnerability to changing climate patterns. It is also worth mentioning that agriculture is both the cause and the solution to climate change. Thus, mitigative measures aimed at reducing the effects of climate change must begin from the inception of land use decisions.

Adoption of CSA practices by communal livestock farmers is not easy because of many barriers that exceed the underlisted. Some of these barriers include age of farmers (many older farmers are engaged in communal livestock farming), poor educational status, low farm income, inadequate farm experience, limited land size, lack of farm input/financial resources, infrequent contact with agricultural extension officers, and lack of exposure to media. Others include poor agricultural production activities, lack of membership to agricultural associations, and misperceptions of the impact of climate change on the environment [4-6].

Considering the aforementioned bottlenecks, the authors sought to provide answers to these challenges and to create pointers that may kickstart the effective adoption of CSA by communal livestock farmers in South Africa. To successfully achieve these, issues such as the prevalent age of communal farmers, their educational level, the relationship they have with extension officers, the financial mechanisms currently available to them and the strategies that are used in other countries that have successfully adopted CSA must be brought to the table and discussed.

Firstly, it has been reported by Mutuku [7] that most communal farmers are elderly and CSA practices are too complex for them to understand. Secondly, the educational level of communal livestock farmers is very limited and this will impede the extent to which such CSA technologies will be understood, accepted and practiced. Thirdly, it is important for extension services to provide information (education) on beneficial practices to farmers because they are the carriers of information to farmers. Training of extension officers will put a tremendous amount of influence on communal livestock farmers to adapt to the changing climate and adopt CSA practices [8]. Suffice to say that a well-managed livestock system is very important with respect to increased productivity, provision of services that benefit the ecosystems and the reduction in GHG emissions.

Furthermore, researchers have shown that farmers who do not have close relationships with extension officers struggle or show no means to adopt climate smart practices in Malawi and South Africa [9]. A lack of information and support from the government, private institutions, and other commercial farmers may also contribute to low or no adoption of CSA practices by communal livestock farmers in the Free State province and in South Africa as a whole. Amongst others, a lack of support by the relevant government departments includes inaccessibility of capital for broader farm investments and absence of or inadequate training of communal livestock farmers on CSA practices [10].

\section{Methodology}

This was a desktop review, which employed the use of various scientific search engines like Google Scholar, Scopus, ScienceDirect, EBSCO Host etc. to source for peer-reviewed published data. Relevant academic reports and government reports, unpublished farmer gazettes, and articles providing sound statistical data and figures on climate smart agriculture and data were also consulted. The literature search was performed between 2020-2021 and it aimed to review the past and present status pertaining to the adoption of climatesmart agricultural practices by communal livestock farmers in South Africa. The impact of animal agriculture on the climate was firstly discussed to set precedence for the subject matter. Keywords and topics such as "climate smart agriculture", "communal livestock 
farming", "the impact of climate smart agriculture on communal livestock farmers", " climate smart animal agriculture", "communal livestock farming in South Africa", "effect of climate change on communal farming", "climate smart agriculture and communal livestock in Africa", "climate smart agriculture and extension services", "communal farming and technology adaptation", etc. were imputed in to produce the desired information. Search results in line with the aim of this review were included and other results that did not fit the purpose of this study were excluded.

Information published in the English language in peer-reviewed articles, government reports, unpublished farmer gazettes, conference papers, or book chapters formed part of the inclusion criteria. Others included information that referred to developed countries and developing economies on the subject matter, and data that focused on the agricultural sector and had at least one of the CSA pillars.

The exclusion criteria included information that was not written in the English language, data that focused on non-agriculture-related sectors, and data that addressed none of the CSA pillars or the impact of climate change.

The preliminary search yielded more than 640 documents, amongst which 280 of them were presumed useful for the review. Endnote version 20 software was used to screen the search results and eliminate duplicates. A full text review was done and after further literature synthesis, 101 documents, which included 3 book chapters, were used for this review paper. The included information was found useful in terms of expanding the frontiers of knowledge on the adoption of climate-smart agriculture by communal farmers. Methodologies used in other publications that were reviewed in this paper included article reviews and research studies conducted by the use of quantitative, qualitative or mixed methods data. It should be noted that this article was intended to dwell majorly in the geographical regions of South Africa, however, mention is made of other countries that have similar results with the subtopics. Bearing in mind the aim of this paper, synthesized useful literature with similar trends were grouped and analyzed. Constructive conclusions were also made.

\section{Impact of Animal Agriculture on Climate Change}

Livestock farming represents a threat towards the environment [11]. Its major impacts are seen in the high records of deforestation, land and water pollution, and greenhouse gas (GHG) emissions. Livestock production contributes $96 \%$ of deforestation at global levels [12] by means of grazing, fodder, and feed production. Additionally, pesticides, herbicides, fertilizers and animal manure management are major contributors to land pollution and water pollution [8]. Methane and nitrous oxide gases are the most important greenhouse gases produced by animal agriculture. According to [13] methane affects global warming 28 times more than carbon dioxide, while nitrous oxide, which arises from the storage of manure and fertilizers, contributes to global warming 265 times more than carbon dioxide. Therefore, livestock production contributes and suffers from the effects of climate change.

\subsection{Deforestation}

The main cause of clearing of forest is caused by the increasing demand for animal products, which invariably results in obtaining more pastures for the increasing animal numbers [11]. At the global level, deforestation is driven by agricultural expansion, which accounts for $96 \%$ of deforestation. Political, cultural, and socio-economic factors, including unsound policies and weak governance, corruption, landlessness and unclear allocation rights, migration, rural poverty, and a lack of investment and financial resources are indirect drivers of deforestation at the local level [12].

Agriculture is the main driver of deforestation in Africa. Deforestation in the Congo basin rainforest is caused by local subsistence activities by poor farmers and villagers who rely on forest lands for agriculture and fuelwood collection often using slash-andburn/fallow techniques (Figure 1) [14]. There are approximately 10,000 species of tropical 
plants in the Congo Basin and a huge variety of animals, including big mammals like African forest elephants, forest buffalo, chimpanzees, bonobos, and a number of subspecies of gorilla. Some of these species have a significant role in shaping the character of their forest home. The South African forestry industry contributes $9.8 \%$ of the country's gross domestic product (GDP) and it is a home to about 23,420 species of vascular plants and 1632 known species of amphibians, birds, mammals, and reptiles, of which $13.9 \%$ of these species are endemic. The natural beauty will all be greatly affected following the loss of forested areas [15].

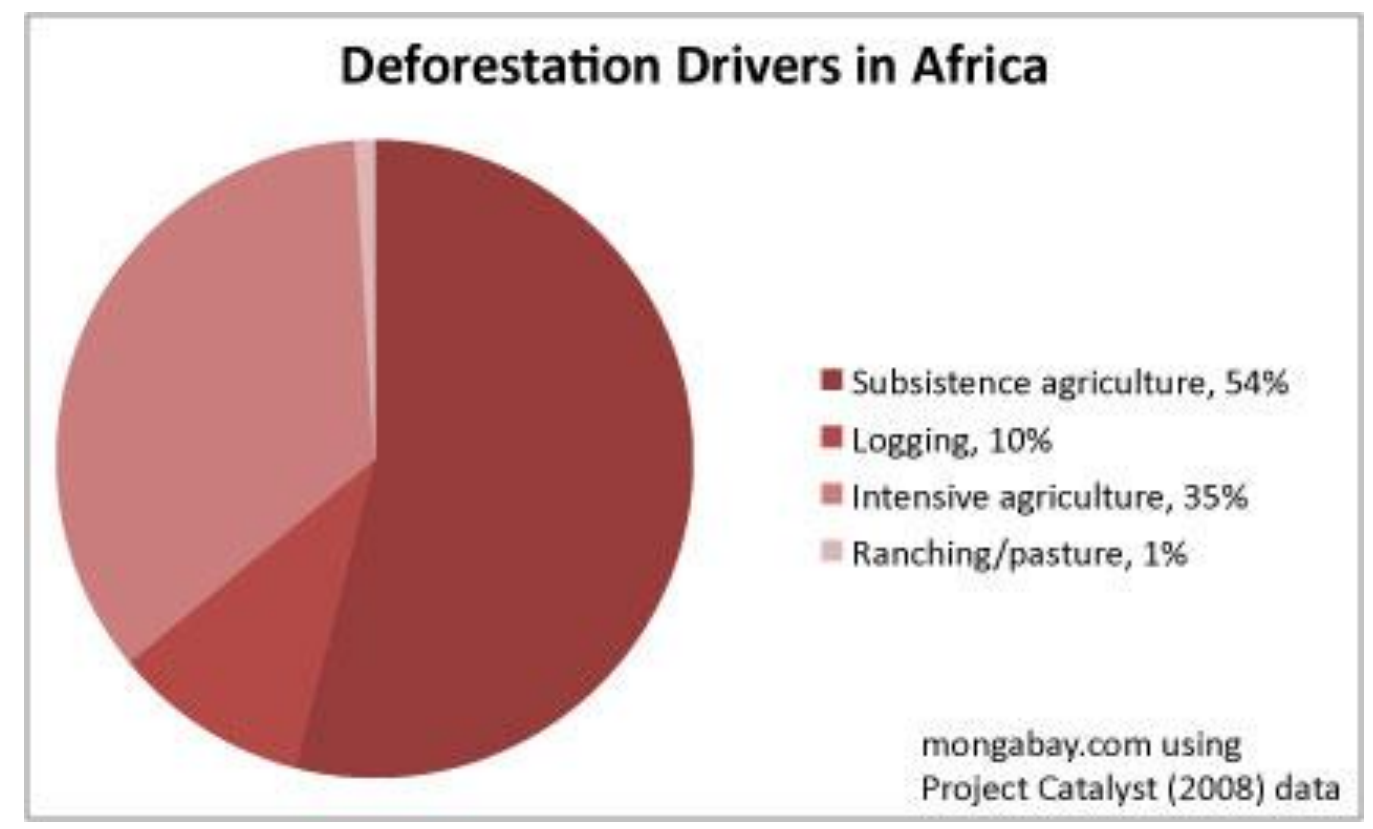

Figure 1. Reprinted with permission from Butler, R. Drivers of Deforestation, Copyright 19942020 [14].

Deforestation in southern Africa and Tanzania is primarily the consequence of human population growth, which results in increasing expansion of agricultural lands for more food production and grazing land $[16,17]$. In addition, the increase of income in many countries creates a greater demand for meat, other cash crops, and animal feed, given that approximately $40 \%$ of the harvested crops in the world are used as feed for animals [11].

It has been reported that reducing deforestation protects biodiversity and livelihoods in forest-dwelling communities [18]. Agroforestry is an integrated approach to the production of trees and non-tree crops or animals on the same land [18] and it is an important measure that is used to counter the effect of deforestation. Agroforestry is important in both climate change mitigation (carbon sequestration, improved feed, and consequently, reduced enteric methane) [19]. This system has long been practiced in South Africa through what is known as the Taungya system, which is the management of forests in which land is cleared and planted initially to produce food crops [20].

Kaczan, Arslan, and Lipper [21] mentioned agroforestry as a climate-smart practice, which is also undertaken in Malawi and termed "fertilizer tree systems". Communities in Cameroon strengthened agriculture by using agroforestry practices by establishing four tree nurseries, each with 10,000 seedlings on their farmland, to reduce the need for agricultural expansion into the forests, reducing deforestation and degradation. Additionally, a silvopastoral system as an agroforestry arrangement is another strategy that can be successfully implemented in South Africa [22]. Silvopastoral systems in Africa involve extensive open grazing by free-roaming animals under scattered natural stands of trees and shrubs. The system combines forestry and grazing of domesticated animals on pastures, 
range land, or on-farm. This system also provides pastures for livestock in the dry season and improves pastures and fodder banks [23].

The benefits of silvopastoral system innovations are clearly visible, although the system requires correct management to implement in order to get successful results. A landscape approach was suggested by FAO [2], as an approach to reduce deforestation. This approach would promote high-carbon stock land uses in forests and in agricultural areas and would contribute to halting both deforestation and forest degradation while meeting future demands for food and nutrition.

\subsection{Water and Land Pollution}

Earlier reports by the United Nations have shown that South Africa's population will be around 65-67 million by 2030 and it is by far the most important driver for the demand for increased food and livestock products [21]. Water pollution is a global challenge that has increased in both developed and developing countries, challenging the economic growth as well as the physical and environmental health of billions of people [24]. The decline in rainfall, water scarcity due to drought, and farm profitability, has left South Africa with less than two-thirds of the number of farms it had in the early 1990s [25].

Seventy percent of water abstractions worldwide are caused by the agricultural industry [8] through water pollution. This is as a result of the deposition of animal excreta, feeds, antibiotics, fertilizers, carcasses, and hormones. [11]. Furthermore, the agricultural industry in South Africa also has to cope with unpredictable seasons, low and variable rainfall, droughts, gradual loss of soil fertility, soil degradation, veld fires, and bush encroachment, all of which are all fall-outs of climate change. Increasing pressures by human and livestock populations are also regarded as culprits [25].

A total of $69 \%$ of South Africa's land surface is suitable for grazing, and livestock farming is by far the largest agricultural sector in the country [25]. According to Gbetibouo and Ringler [26], South Africa's grazing land is stocked beyond its long-term carrying capacity. The South African Wildlife Foundation (WWF-SA) [25] has further reported that overstocking is most evident in the communal rangelands of Limpopo, KwaZulu-Natal, and the Eastern Cape provinces, which support more than half of South Africa's cattle production. Overstocking causes trampling and crusting of the soil and denudes the veld of vegetation.

Pesticides, herbicides, and fertilizers that are used on crops fed to animals are major contributors to land pollution. Many harmful substances reach our lakes, rivers, and eventually groundwater, leading to widespread contamination of waterways and groundwater and decreased water quality [24]. The use of artificial fertilizers damages soils by making them lose their water holding capacity, which invariably makes them subject to erosion. Poorly managed fertilization can also change the species composition and decrease the basal grass cover. This reduces productivity and increases water run-offs and erosion [24].

Increased carrying capacity can be achieved through simple techniques like planting pastures, adding fertilizers, and planting additional palatable species. Furthermore Ndhlovu and Mpofu [27] mentioned that conservation agriculture (CA), popularly known as "Farming the God's Way", is one of the most popular climate change adaptation techniques in one of the districts in Zimbabwe. The system is also being introduced in South Africa by land care programs that aim to teach communities to responsibly manage the land by conserving vegetation, water, and biological diversity in their area [28].

Other CSA practices that are currently adopted in South Africa include water conservation, which utilizes the in-field rainwater harvesting technique; no-till technique, which ensures that the soil is less prone to erosion and effectively retains organic matter, water, and nutrients; the use of rotations; intercropping; and maintenance of permanent soil cover [25]. Furthermore, in the KwaZulu-Natal province of South Africa, the problem of maintaining soil fertility and soil structure is solved by using animal manure as alluded by [29]; their study showed that $40 \%$ of the farmers reported improved soil fertility following the application of manure. 
Some of the CSA strategies to deal with water pollution and land pollution suggested by WWF-SA [25] to farmers are to ensure that stocking rates are within the land's carrying capacity, based on the commercial stocking rates for a given area and the present veld condition. Also, the reduction in the use of pesticides and herbicides that cause a decline in soil micro-organisms is advised. Other strategies include clearing alien vegetation, which is a cost-effective way of increasing water supply on the farm; using plant cover crops to prevent bare ground when the actual harvest is over; preventing soil erosion and loss of waterways; the use of wetlands; and planting grasses, trees, and fences along the edges of a field that lies on the boarders of water bodies. Lastly, reduction in tillage of the fields in order to reduce runoffs, soil compaction, and erosion; maintain or improve veld condition and the health of the soil by ensuring appropriate rest periods after relevant grazing and/or fire events; prevention of overgrazing, trampling, and soil erosion; and the rehabilitation of degraded veld are the other approaches [25].

\subsection{Greenhouse Gas (GHG) Emissions}

Global emissions of methane have risen by nearly $10 \%$ over the past two decades, resulting in higher-level atmospheric concentration of greenhouse gasses. The impact of GHG emissions on climate change was witnessed in 2015 in South Africa, where a total livestock mortality rate of 252880 was recorded [30]. The delay in rainfall led to late plantings, a decline in available feeds, fodder, and limited crop production [30]. Lipper [31] also mentioned that changing temperature patterns threaten the agricultural industry and disrupt food markets and food supply to the resource-poor communities that depend largely on agriculture for their livelihoods.

The direct and indirect contributions of livestock to GHG emissions include animal physiology, animal housing, manure storage, manure treatments, land application, and chemical fertilizers [32]. Furthermore, Gerber [3], stated that the livestock manure management and normal digestive processes (enteric fermentation) contribute $44 \%$ of the world's anthropogenic methane gas $\left(\mathrm{CH}_{4}\right)$ emissions. This buttresses the submission that global emissions of methane have risen by nearly $10 \%$ over the past two decades, resulting in a higher-level atmospheric concentrations of greenhouse gasses [33]. In addition, Moran [34] also reported that global livestock production contributes an estimated $18 \%$ of anthropogenic greenhouse gas (GHG) emissions, mainly in terms of the release of methane and nitrous oxide gases.

Kenya showed various CSA practices that were implemented successfully by farmers to reduce the emissions caused by agriculture through the Mitigation of Climate Change in Agriculture Program (MICCA) pilot project, incorporated CSA practices like conservation tilling (CT) and improving animal breeds to create carbon sinks. A dairy herd management project was also introduced, which involves managing livestock nutrition so as to ensure that feed is broken down as efficiently as possible and with minimal production of methane gas [35].

Livestock manure emissions may be used as biogas, which may be utilized to generate electricity, heat, and fuel [13]. Farmers in China are already using this CSA practice to convert greenhouse gas to energy. Farmers are involved in a CSA project that channels the waste, mostly from pigs, to sealed tanks where it is converted into gas and it is used for cooking. This project incorporates straw in their biogas, where it is transformed along with pig manure into fertile compost [35]. The same project was carried out in Outeniqua research farm in the Western Cape province of South Africa, where a biogas fermenter was set up to digest manure from the research dairy farm and manure was converted to biogas and then to electricity for use by the dairy farm [36].

In reviewing literature pertaining to GHG emissions, it has been noted that animal emissions vary according to seasons. According to Gaitán [37], these emissions are usually higher in the dry season than in the wet season. Livestock farming is also responsible for overgrazing, land degradation, and loss of forest. These practices release large quantities of greenhouse gases into the atmosphere. The research on GHG emissions, especially in 
communal areas of South Africa, is limited. This proves that there is partial information about the various mitigation strategies that are adaptable in South Africa, especially as it relates to communal livestock farmers. Knowledge about changing climatic conditions and the different trade-offs that are involved in communal livestock areas in South Africa are definitely beneficial in implementing mitigation policies [35].

\section{Implementing Climate-Smart Agriculture in Livestock Farming}

The impact of animal agriculture on climate change has so far been recognized. Hence, implementing climate-smart agriculture for communal livestock farmers will not come at a low cost. Some of the strategies highlighted in this section have already been adopted by some farmers. These measures include: the use of adaptable breeds; manipulation of rumen ecology, feed types, and feeding; education and extension services; and improved policies. Climate-smart agriculture as the way of farming has a maximum ability to rescue countless numbers of smallholder farmers across South Africa and the neighboring countries and its practices are both economically and environmentally friendly.

\subsection{Adaptable Breeds}

Heat stress in livestock is mostly experienced when the temperature humidity index (THI) is higher than 72 THI [38]. Heat stress causes adverse behavioral, chemical, physical, nutritional, physiological, and metabolic responses in livestock, which militates against preserving cell integrity and survival [39]. Discomfort caused by heat stress has known effects, such as reducing milk yields in dairy cattle and negatively influencing conception rates across almost all breeds and species of livestock [40].

The report from DAFF [41] has shown that farmers in the Free State province farm with animal breeds that they know or breeds that can be easily accessed and not necessarily as a result of the adaptive potential or characteristics of that breed. Therefore, it is important to identify breeds with inherent genetic capabilities to adapt to climate change. Kadzere [42], mentioned that indigenous breeds thrive with minimum input compared to imported breeds, and these breeds are pivotal to the development of climate-smart animal agriculture. It is worthy of note that communal and smallholder livestock farmers in South Africa have been practicing CSA for a long time through traditional practices [43]. The majority of smallholder farmers in South Africa are targeting indigenous livestock breeds like Afrikaner, Nguni, Boer goats, free-range chickens, and locally developed composites like Bonsmara and SA Mutton Merino, while recognizing the adaptability of other breeds that have been in these areas over many generations [44]. All these breeds are known to be hardy, drought and disease tolerant, and have a lighter impact on the environment.

Changes in breeding strategies can help animals increase their tolerance to heat stress and diseases and improve their reproductive and growth development [45]. Some of the CSA management strategies that can be implemented to reduce heat stress include mechanical cooling, such as forced ventilation, water sprays, and shading. However, this can be difficult to apply, especially to livestock on pasture as this offers relief from hyperthermia for a short time [20,46]. Furthermore, a study in Nigeria [5] and a report from Schulze [47] both stated that keeping a large number of livestock in a limited space is a challenge. In such circumstances, stall feeding as a CSA practice becomes even more appropriate and the manure from dairy units can be used to produce biogas, which will reduce deforestation, thus, minimizing the release of carbon dioxide $\left(\mathrm{CO}_{2}\right)$ to the atmosphere [5].

Existing evidence on the impact of CSA on livestock farmers is very limited, only 3.5\% when compared to $93 \%$ from crops. Nearly all data on livestock are on improved diets, with few on improved breeds [48]. Some of the most known livestock adaptation strategies, such as pasture management technologies and animal housing, are absent from the data reviewed by Rosenstock [48] in east and southern Africa. Rosenstock [48] additionally mentioned that this is an important gap to be filled as these technologies are also relevant as mitigation pillars of CSA. 
Investments geared towards equipping farmers with much needed knowledge will help farmers to know which breeds are adaptable in their geographical location and they can be informed on which breeds can tolerate different climatic changing patterns. The Agricultural Research Council (ARC) in South Africa also promotes adoption of an integrated crop-livestock system that effectively mitigates, adapts to, and reduces vulnerabilities to climate variability and climate change $[43,49]$. Educating communal livestock farmers about different breeds and their characteristics will not only help them with knowing how to choose adaptable breeds in their area, but it will also assist them with getting better prices at the markets, while saving the planet.

\subsection{Manipulation of Rumen Ecology}

It is now possible to increase or decrease the results of rumen digestion through rumen manipulation methods like the use of ionophores in feed, defaunation, and diet manipulations amongst others. Rumen is the first stomach chamber of ruminants; it is a compartment which receives food or cud from the esophagus and where fermentation occurs [50]. Sixty percent of total digestion takes place in this compartment even though the rumen wall does not secrete enzymes [51]. This chamber contains different types of microbes including bacteria, protozoa, and fungi.

The various challenges that are currently facing the livestock sector are to reduce the high cost of feeds, improve product quality, and lessen the impact of production on the environment. The production values of $\mathrm{CH}_{4}$ and $\mathrm{CO}_{2}$ by rumen microbes are estimated at $400 \mathrm{~L}$ and $600 \mathrm{~L}$ d-I respectively in adult cattle. These high values contribute to the greenhouse effect, which is now threatening our planet $[35,52]$.

There are several strategies that have been proven to reduce the emissions caused by ruminants. One of these includes rumen fermentation, which is the process that converts ingested feed into energy sources for the host [53]. Manipulation of rumen fermentation is crucial for improving nutrient utilization and productivity of animals. The more efficient the rumen is, the better will be the synthesized fermentation end-products [54].

Manipulating ruminal fermentation is intended to enhance beneficial processes and remove, decrease, and change processes that are harmful to the host. This can be achieved through maximizing the efficiency of feed utilization and increasing ruminant productivity (milk, meat, and wool) [54].

The genetic and non-genetic options are the other examples of rumen manipulation and ecology management methods. These two approaches employ the use of bacteriostatic chemicals such as ionophores, bacteriocins, feed additives (e.g., fats and oils), synthetic chemicals, natural compounds, and vaccination to inhibit methanogens. Enhancing non-methanogens through diet manipulations and the use of inoculants is also a rumen manipulation strategy [54]. The adoption of bio-digestion can increase farm profits by $10 \%$ to $20 \%$ and help reduce the environmental impact of livestock production [55]. Also, introducing new species or strains of microorganisms into the gut has a great potential to increase digestibility of feedstuffs and to improve animal health and growth [56].

Defaunation is the process of making the rumen of animals free of rumen protozoa and the animal is called a defaunated animal [56]. Rumen protozoa contribute $40-50 \%$ of the total microbial biomass and enzyme activities in the rumen. Using chemicals (copper sulphate, manoxol, and sodium lauryl sulphate) is another method of defaunation for obtaining animals free from rumen ciliate protozoa [57]. Defaunation has been proven to significantly decrease the methane production compared with the normal faunated animals [58]. There is ample scope to manipulate the rumen by feeding local plants, tree leaves, or agro-industrial by-products to defaunate animals for improved productivity.

Rumen manipulation has, therefore, been proven to be effective in increasing the efficient use of local feed resources and enhancing productivity in ruminants [59]. Since $8-12 \%$ of the digestible energy ingested by ruminants is lost in the rumen as methane, higher methane output of up to $15-18 \%$ of the digestible energy may be produced where cattle are fed on poor quality forage [59]. 
The use of unconventional feedstuffs may contribute to decreased feeding cost and environmental impact through reduced methane emissions. According to Patra [60], the methods to effectively reduce methane production in the reticulo-rumen include the use of synthetic chemicals; supplementation of organic acids like fats and oils, ionophores, and halogenated compounds; and processing of feeds and microbial feed additives.

\subsection{Feed Types and Feeding}

Climate change is heavily affecting South Africa and the agricultural industry at large. Feed production accounts for $47 \%$ of GHGs from livestock farming and improved foragebased systems [3]. In low rainfall areas, more farmers are interested in CSA technologies to minimize the climatic risks, mostly water scarcity and droughts [61].

Drought results in high prices of basic foods and it has been reported that cattle farmers are more vulnerable to drought when compared to other species of livestock production [62]. The use of manure in the form of synthetic fertilizers for forage contributes to GHG emissions. Global feed production and processing and transport contributed $3.2 \mathrm{Gt}$ $\mathrm{CO}_{2}$ eq, accounting for $45 \%$ of the sectors' emissions $[3,21]$.

Forage grasses and legumes that are resilient to stress provide feed for livestock during drought or waterlogging. The use of drought-adapted forage legumes and concentrates in crop-livestock systems also provides high-quality feed in the dry season [63]. In Norway, the feed ration for dairy cows consists of $45 \%$ and $42 \%$ silage and concentrates, respectively [34]. This, on the other hand, might be a difficult mitigation tool to adapt in some provinces in South Africa as it will surely depend on the costs, knowledge of farmers, and availability of feed.

In the North West province of South Africa, fodder banks are constructed and promoted to maintain healthy productive animals, thereby adopting CSA practices. Moreover, in India, important CSA mitigation measures adopted by livestock farmers for improving livestock include adding digesters and $\mathrm{CH}_{4}$ inhibitors in feed and enhancing the number of crossbred animals that have lower $\mathrm{CH}_{4}$ emissions per unit of production [64]. Ayantunde [65] mentioned that in the Sahel region, digestibility and protein content of the feed, herd, and grazing management, and supplementary feeding are important factors in feed management [65].

On-farm CSA practices in livestock production that have been adopted in Uganda include silvopastoral systems (i.e., converting degraded extensive treeless pastures into a richer and more productive environment, where trees and shrubs are planted interspersed among fodder crops such as grasses and leguminous herbs), improved feeding regimes, and grazing land management (rotational grazing and forage conservation) [66]. Off-farm CSA related services include crop weather-index-based insurance and using automated weather stations to monitor specific parameters and triggers [67].

Pasture management is very important when it comes to proper nutritional requirements of livestock [68]. The use of correct pasture management practices, conservation agriculture (CA), crop rotation, and an intensive grazing system could be important mitigative practices that could guarantee more efficient conversion of forage into economically available products, hence, culminating in reduced $\mathrm{CH}_{4}$ and $\mathrm{N}_{2} \mathrm{O}$ emissions [3]. Furthermore, supplementing poor quality forages with fodder trees, as in silvopastoral systems, or with legumes, as well as increased protein content of feeds, can also improve digestibility and reduce the overall methane emissions per unit of product [66].

Some of the useful grazing management practices highlighted by Bezuidenhout [69] in an article published by Farmers Weekly magazine have been shown to be effective to livestock farmers in many parts of the South Africa. These practices include setting aside forage by postponing grazing while forage species are growing, ensuring equal grazing of various species to stimulate diverse grasses, and improving nutrient cycling and plant productivity. Others include developing healthy pasture root systems, maintaining plant cover at all times, and promoting natural soil forming processes. The results of a study in the Eastern Cape province of South Africa showed a different view as communal 
livestock farmers in that area highlighted a lack of strong local-level institutions, little to no knowledge of veld management, and inadequate fencing of paddocks as constraints that contribute to the lack of adopting CSA pasture management practices [70].

It is common knowledge that a well-managed pasture or feeding system requires a knowledgeable farmer, financial support, skilled labor, and technical resources to actualize it. We can arguably say that there is little impact of CSA in terms of feed management in some provinces and this indicates that the government of South Africa, the Department of Agriculture and Rural Development, and the private sector needs to actively evaluate the land and the equipment needs of farmers and provide farmers with specific CSA pasture management and feeding aids depending on the type of need and the location.

\subsection{Education and Extension Services}

Agricultural extension is a process of working with farmers to improve production and overall livelihoods [71]. In South Africa, extension officers are qualified workers appointed by the Department of Agriculture and Rural Development (DARD). These officers have a crucial role to play in the adoption of CSA practices in communal livestock farming. The main duties of extension officers are to help to facilitate sustainable agricultural productivity through raising awareness, capacity building, and the provision of up-to-date information, like an early warning of drought, input supply, climate change, adaptation strategies, new technology development, weather forecasts, access to markets, and credits to farmers [72].

Maka [72] conducted a study in the Eastern Cape province of South Africa and the results revealed that $68 \%$ of farmers claimed they have limited or no access to extension services in that area. This seems to be a norm as the beneficiaries of the Nguni cattle project in Raymond Mhlaba Local Municipality in that province also claimed that no extension support services were received by farmers to improve their socioeconomic status [73]. Similarly, in Mozambique, 52\% of small-scale farmers were not adopting CSA practices due to lack of knowledge and financial capacity to invest in on-field interventions [68]. As reported by Nyasimi [74], limited knowledge about promising initiatives can lead to poor uptake of CSA practices. One of the reasons for lack of services from extension officers is that they may be unequipped to deal with the current challenges of climate change. There should be specific CSA-related training programs for extension officers to equip them in assisting farmers to deal with the challenges of climate change [72].

Interestingly, in some parts of South Africa (Mthonjaneni, Umhlathuze Gqumashe villages, etc.) farmers have adopted a number of strategies to cope with climate change and its resultant variabilities. Practices such as crop rotation, changing the time of farmer operations, introducing diverse crop varieties, increased efficiency of irrigation, promoting climate change awareness and education amongst each other, and working together with other farmers are some of the adopted measures [6,74].

Conservation agriculture (CA) is an example of a successful project implementation in South Africa and the key approach is to train senior agricultural officials who will transfer knowledge to the farmers $[28,75]$. The implementation of CA in western Zambia has also shown a positive impact through increased yields. There was greater productivity on CA fields and the acquisition of seeds increased. These results were obtained from an app that was used in Namibia named the "Event Book" and "Mobile App" [75]. In Malawi, likewise, Dr Ngwira [76] also acknowledged that Malawian farmers find CA more profitable as it requires less labor for land preparation, weeding, and other agricultural practices.

The government of Uganda has trained 58,000 farmers in CA and 28,000 farmers have adopted and are practicing conservation agriculture, and the adoption of CA is increasing, as well as the knowledge level of farmers in the country [24]. Ghana also introduced a private ICT-based platform that provides market price alerts, climate-smart agricultural advice, weather forecasts, and voice messages on CSA practices sent out to farmers in the language of their preference. This platform has so far trained and improved access of about 
835 farmers (of which 33\% have been females) to the use of down-scaled seasonal forecast and climate-smart agriculture technologies and practices through mobile phones [77].

In Nigeria, a study revealed that contact with extension agents, which denotes access to information, has positive effects across all the CSA practices in the country. This indicates that contact with extension services increases the likelihood of adopting CSA practices [5].

Since extension officers are the main carriers of information to communal livestock farmers, they should take the responsibility to ensure farmers get information on climate change, climate change impacts, and CSA. In view of these results from other countries and South Africa, it shows that implementation of CSA is not difficult for farmers to adopt, they just need knowledge and guidance. The use of media along with extension services should be increased in pushing awareness and information about CSA practices to communal livestock farmers in South Africa in order to help them cope and adjust to climate change. Therefore, this study infers that extension services must go to farmers to provide training and disseminate knowledge.

\subsection{Government Policies}

Climate-smart agriculture and planning of agricultural adoption strategies requires clear policies in order to be effectively implemented. Policymakers in West Africa reinforce the adaptive mechanism to deal with negative effects of climate change as a top priority [77]. In addition, Ben [78] mentioned the National Environment Management Policy, Forestry Policy, and National Policy for the Conservation and Management of Wetland Resources as policies that are active in Uganda. Despite this comprehensive policy framework, there is still a lack of strategic and comprehensive integrated planning for CSA in Uganda.

Contradictions with the statement made by Mnkeni and Mutengwa [44] were seen when other investigators reported that impressive progress has been made in the formulation of CSA policies in South Africa. Contrarily FANRPAN [8] mentioned that CSA policy has not yet been formulated in South Africa, but the Climate Change Sector Plan (CCSP) for Agriculture, Forestry, and Fisheries has been completed and made public for comment. Uganda is no exception as government agencies responsible for implementing environment policies, including adaptation interventions, are under resourced [8].

Designing policies that aim to improve factors affecting the adoption of CSA for smallholder farming systems have great potential to improve CSA compliance [44]. Policy initiatives and developments that promote CSA in Africa do exist and South Africa is actively responding to climate change challenges, which requires considerable changes in the national and local governance, legislation, policies, and financial mechanisms [79].

The Department of Agriculture, Forestry, and Fisheries (DAFF); National Departments of Environmental Affairs (DEA), Water Affairs (DWA), Rural Development and Land Reform (DARD); state-owned research institutions including the National Research Foundation (NRF), Agricultural Research Council (ARC), and Council for Scientific and Industrial Research (CSIR); and farmer organizations like Red Meat Producer Association of South Africa (NARPO) and the National African Farmers Union of South Africa (NAFUSA) are stakeholders involved in formulating CSA policies in South Africa [44]. In Lesotho, Vuna provides policy influence, education, information, finance, and market knowledge for adopting CSA. Climate-smart agriculture policy is likely to be completed in South Africa after the CCSP (Climate Change Sector Plan) has been approved [8].

Despite the delay in CSA policy in South Africa, the good thing is that some farmer organizations have started to independently adopt and promote CSA principles. These organizations include the Red Meat Producers Organization (RPO), the KwaZulu-Natal (KZN) No Till Club, the Grain Producers Association of South Africa (Grain SA), the South African Wine and Fruit Industries (SAWFI), sugarcane growers, the National African Farmers Union of South Africa (NAFU-SA), the National Wool Growers Association (NWGA), Mohair SA, Dairy SA, and the Ostrich Business Chamber (OBC) [80]. 


\section{Challenges to the Adoption of Climate Smart Agriculture}

Smallholder agriculture in southern African countries is practiced as a way of life. Agricultural productivity depends on people, principles, goals, knowledge, resources, and decision-making processes, amongst others [10]. This section presents the various barriers that prevent communal livestock farmers from adopting climate-smart practices. These challenges include a lack/dearth of infrastructure, inadequate policies and government services, inaccessible road networks, and the human factor (the farmers' beliefs and willingness to adopt modern technologies). These barriers have been implicated in the low/slow response of communal livestock farmers to CSA adoption.

\subsection{Adoption of Technology}

The rate of adoption of technology by communal farmers is very low [81]. This is due to the level of education and information-seeking behavior of some of the farmers. Kunene [82] further mentioned that the high illiteracy level of most communal farmers as a stumbling block for the adoption of new technologies.

\subsection{Government Services}

Veterinarians and extension officers are assigned to every district in the agriculture sector, where they provide expertise to the farmers in South Africa. Nonetheless, Gwala [83] reported on the poor quality of work done by the extension services provided by the government in order to help communal farmers. Liebenberg [84] also stated that 8 out of 10 extension officers in South Africa are insufficiently qualified to carry out their responsibilities. Despite this challenge, the extension officers will remain a major source of information and knowledge to rural farmers.

\subsection{Infrastructure}

The most prominent infrastructural challenges for communal farmers in South Africa are transport and holding facilities [83]. Lack of facilities like temperature-controlled barns, crush pens, and dams are some of the struggles experienced by smallholder farmers. Available and affordable farm equipment are non-negotiables for better productivity since livestock is an inflation-free resource for communal farmers and a store of wealth. Farm animals can be sold to meet farmers' daily, weekly, and monthly expenses like school fees, medical bills, and household expenses [85].

\subsection{Inadequate Cutting-Edge Technology Awareness}

The use of modern technology creates opportunities for communal livestock farmers. ICT- based information sources available to smallholder farmers in South Africa include radio, television, and smartphones [86]. Similar results were reported in the southern district of Botswana, which revealed that the most used technological devices in communal areas were smartphones $(89 \%$ ), while local radio and television accounted for $59 \%$ of use respectively [87]. Lekopanye further recommended that the radio stations and television broadcasts need to incorporate livestock programs that combine mobile technology with radio and television, where participants will be involved in the various awareness topics through calls or short messages.

\subsection{Farm Location and Inaccessible Road Networks}

Long distances from major cities and poor road networks in communal areas affect the ability of farmers to adopt modern technologies and attract many buyers. Mthi [88] reported that poor accessibility of roads was ranked as the eighth most important constraint affecting livestock production in the Eastern Cape province of South Africa. Remote locations with poor states of roads result in high costs of moving livestock to markets and hinder marketing efficiency [89]. The results from the study concurred with the findings of Makhura and D'Hease [90,91], who reported that the smallholder farmers have been neglected in terms of infrastructural support by past governments. 


\subsection{Human Factor (Farmer Beliefs and Willingness to Adopt Modern Technologies)}

The famers' decisions on whether and how to adopt modern technologies are conditioned by the active interaction between the characteristics of the technology, array of conditions, access to credit, capital availability, and the farmers' circumstances [92]. Profitability is a major concern to farmers, thus, the opportunity to witness an investment in profitable technology by a fellow producer with similar facilities and resources often assists in decision making and the willingness of the farmer to adopt the modern technology [93].

\subsection{Climate Smart Agriculture Law and Policies}

The South African government in 2019 published the Carbon Tax Act (Act. No. 15 of 2019), a climate change law to stabilize the greenhouse gas concentration in the atmosphere [94]. Smallholder farmers and local farming communities play a crucial role in implementing CSA practices. However, in many cases, locally established user rights are not legally formalized. Unclear tenure arrangements chase away external investors due to the risk of inconsistency and lack of accountability. A well-designed policy framework and law require relevant institutions and authorities to develop strategic institutional plans to ensure the effective implementation of new laws and other legal provisions [94].

\section{Conclusions}

This article reviewed the adoption of climate-smart agriculture (CSA) by communal livestock farmers in South Africa. The influence of animal agriculture on climate change was also discussed. The findings indicated that the quest to promote CSA will not be cheaply achieved [77]. There is limited research on the adoption of CSA by communal livestock farmers in South Africa. Some farmers are already practicing some aspects of CSA, even though they might be unaware of it. It has been noted that unavailability and unaffordability of technology is a big challenge to smallholder farmers. The media is a valuable source of information for communal farmers on matters of climate change adaptation and CSA adoption. It provides content pertaining to some techniques that are inapplicable to communal farmers or too expensive for communal farmers to implement.

There have been huge differences in the provision of extension services in countries like Uganda and Ghana when compared to South Africa. These countries (Uganda and Ghana) prioritized the education of communal livestock farmers, and this increased their adoption rates. This clearly shows that the implementation of CSA practices is not farfetched, but a lack of information, support, and financial capacity to invest in on-field interventions might be hindering extension service training in South Africa, indicating that improvements are possible.

Mitigation tools to reduce $\mathrm{CH}_{4}$ and $\mathrm{N}_{2} \mathrm{O}$ emissions that are used in developed countries like China are not always applicable to developing countries like South Africa. This is due to a lack of information and insufficient resources to implement them. South Africa must use the mitigation tools adaptable to their conditions with adequate consideration of costs, knowledge, and availability.

Similarly, there is a big gap in enacting CSA policies in South Africa. Sound implementation of technologies requires innovative policies; thus, the Department of Agriculture and Rural Development needs to engage all stakeholders to make a common policy that embraces all aspects of the environment that are affected by climate change. The government should improve local capacity in advanced and affordable water supply systems, agricultural solutions, and reliable financial mechanisms in order to implement innovative sound technologies.

Another gap is seen in the deficient awareness and information sharing to communal livestock farmers. The reality of lack of information is a very critical factor to address for the implementation of CSA practices in any country. There is a lot that South Africa can learn from other countries with regard to the benefits of using CSA practices and their implementation strategies and policies. In future, CSA adoption and adaptation studies should focus more on the formulation and implementation of CSA policies relevant to 
the South African environment, considering the educational levels of target farmers, and propose solutions to make adaptability to modern techniques easily applied at local levels.

Author Contributions: Conceptualization, L.M., P.F. and I.N.; methodology, L.M. and I.N.; software, L.M. and I.N. validation, L.M., P.F. and I.N.; formal analysis, L.M. and I.N.; investigation, L.M. and I.N.; resources, L.M. and I.N.; data curation, L.M. and I.N., writing-original draft preparation, L.M. and I.N.; writing-review and editing, L.M. and I.N.; visualization, L.M. and I.N.; supervision, L.M. and I.N.; project administration, L.M. and I.N.; funding acquisition, P.F. and I.N. All authors have read and agreed to the published version of the manuscript.

Funding: This research was funded by National Research Foundation (NRF), grant number: MND200 430518165 and Central University of Technology Postgraduate grant CUT/RGS/grants/214001997.

Institutional Review Board Statement: The study was conducted according to the guidelines of the Declaration of Helsinki, and approved by the Institutional Review Board of Central University of Technology, Free State (protocol code: D FHES 20/01/31a-b and date of approval: 31 January 2020).

Informed Consent Statement: This study is a desktop review, human or animal subjects were not used, and hence, no informed consent was requested or received. Not Applicable.

Data Availability Statement: Since it is a review article, information used was obtained from already published sources and referenced accordingly; hence, no new data was generated and stored in a public or institutional repository.

Acknowledgments: We would like to acknowledge the support of the Central University of Technology postgraduate grant for the financial support [CUT/RGS/grants/214001997]. The financial assistance from National Research Foundation (NRF) [MND200430518165] towards this research is acknowledged.

Conflicts of Interest: The authors declare no conflict of interest.

\section{References}

1. Bonthuys, J. Climate Change: The Human Factor. University of Cape Town News Embed Article. 2019. Available online: http:/ / www.news.uct.ac.za/article/embed/js-2019--03-04-Climatic-change-the-human-factor (accessed on 20 January 2021).

2. Food and Agricultural Organization (FAO). Climate-Smart Agriculture Policies, Practices and Financing for Food Security, Adaptation and Mitigation. In Proceedings of the Global Conference on Food Security and Climate Change, The Hague, The Netherlands, 31 October-5 November 2010.

3. Gerber, P.J.; Steinfeld, H.; Henderson, B.; Mottet, A.; Opio, C.; Dijkman, J.; Falcucci, A.; Tempio, G. Tackling Climate Change through Livestock: A Global Assessment of Emissions and Mitigation Opportunities; Food and Agriculture Organization of the United Nations (FAO): Rome, Italy, 2013; ISBN 9789251079201.

4. Food and Agricultural Organization (FAO). Climate Smart Agriculture Sourcebook; FAO: Rome, Italy, 2013. Available online: http:/ / www.fao.org/3/i3325e/i3325e.pdf (accessed on 28 June 2021).

5. Onyeneke, R.U.; Igberi, C.O.; Uwadoka, C.O.; Aligbe, J.O. Status of climate-smart agriculture in southeast Nigeria. GeoJournal 2018, 83, 333-346. [CrossRef]

6. Abegunde, V.O.; Sibanda, M.; Obi, A. Determinants of the adoption of climate-smart agricultural practices by small-scale farming households in King Cetshwayo District Municipality, South Africa. Sustainability 2020, 12, 195. [CrossRef]

7. Mutuku, M.M. Factors Affecting Smallholder Farmers' Adoption of Integrated Soil Fertility and Water Management Practices in Machakos County. Master's Thesis, School of Agriculture and Veterinary Sciences, South Eastern Kenya University, Kwa Vonza, Kenya, February 2017. Available online: http:/ / repository.seku.ac.ke/handle/123456789/3244 (accessed on 5 May 2021).

8. Food, Agriculture and Natural Resources Policy Analysis Network (FANRPAN). Climate Smart Agriculture in South Africa. Policy Brief Newsl 2017, 1-8. Available online: https: / / www.jstor.org/stable/resrep16462?refreqid=pub-view\%3Aa1b470d58aa0 e670ffba678d72412cd4\&seq=1\#metadata_info_tab_contents (accessed on 28 June 2021).

9. Murray, U.; Gebremedhin, Z.; Brychkova, G.; Spillane, C. Smallholder farmers and climate smart agriculture: Technology and labor-productivity constraints amongst women smallholders in Malawi. Gend. Technol. Dev. 2016, 20, 117-148. [CrossRef]

10. Barnard, J.; Manyire, H.; Tambi, E.; Bangali, S. Barriers to Scaling up/out Climate Smart Agriculture and Strategies to Enhance Adoption in Africa; Forum for Agricultural Research in Africa: Accra, Ghana, 2015; ISBN 978-9988-8502-0-x.

11. Dopelt, K.; Radon, P.; Davidovitch, N. Environmental effects of the livestock industry: The relationship between knowledge, attitudes, and behavior among students in Israel. Int. J. Environ. Res. Public Health 2019, 16, 1359. [CrossRef] [PubMed]

12. ASB. Reducing Emissions from All Land Uses: The Case for a Whole Landscape Approach; ASB Policy Brief No. 13; ASB: Nairobi, Kenya, 2010.

13. Grossi, G.; Goglio, P.; Vitali, A.; Williams, A.G. Livestock and climate change: Impact of livestock on climate and mitigation strategies. Anim. Front. 2019, 9, 69-76. [CrossRef] 
14. Butler, R. Drivers of Deforestation in Mongabay. In Mongabay News and Inspiration from Nature's Frontline; Mongabay: Menlo Park, CA, USA, 2013. Available online: https:/ / rainforests.mongabay.com/deforestation_drivers.html (accessed on 28 June 2021).

15. Butler, R.A. World deforestation rates, rain forest and forest cover statistics, 2000-2006. In Mongabay News and Inspiration from Nature's Frontline; Mongabay: Menlo Park, CA, USA, 2013. Available online: https://rainforests.mongabay.com/congo/ (accessed on 20 January 2021).

16. Pelser, A.J.; Kherehloa, T. Some causes and strategies pertaining to land degradation in southern Africa. S. Afr. J. Agric. Ext. 2000, $29,24-46$.

17. Doggart, N.; Morgan-Brown, T.; Lyimo, E.; Mbilinyi, B.; Meshack, C.K.; Sallu, S.M.; Spracklen, D.V. Agriculture is the main driver of deforestation in Tanzania. Environ. Res. Lett. 2020, 15, 034028. [CrossRef]

18. Britannica. The Editors of Encyclopaedia. "Amazon Rainforest" Encyclopedia Britannica. 2019. Available online: https: //www.britannica.com/place/Amazon-Rainforest (accessed on 21 April 2021).

19. Dickie, A.; Streck, C.; Roe, S.; Zurek, M.; Haupt, F.; Dolginow, A. Strategies for Mitigating Climate Change in Agriculture: Abridged Report. Climate Focus and California Environmental Associates, Prepared with the Support of the Climate and Land Use Alliance. 2014. Available online: www.agriculturemitigation.org (accessed on 26 May 2021).

20. Menzies, N. Three hundred years of taungya: A sustainable system of forestry in south China. Hum. Ecol. 1988, 16, 361-376. [CrossRef]

21. Kaczan, D.; Arslan, A.; Lipper, L. Climate-Smart Agriculture? A Review of Current Practice of Agroforestry and Conservation Agriculture in Malawi and Zambia; FAO: Rome, Italy, 2013; pp. 1-62. [CrossRef]

22. Food and Agricultural Organization (FAO). Introducing of Silvo-Pastoral Systems for Cattle Rising to Sustainably Provide Fodder to Animals in Drought Periods in Bolivia; FAO: Rome, Italy, 2017. Available online: http://www.fao.org/3/CA3564EN/ca3564en.pdf (accessed on 28 June 2021).

23. Ramachandran, P.K. Nair. Agroforestry: Trees in Support of Sustainable Agriculture, Module in Earth Systems and Environmental Sciences; Elsevier: Amsterdam, The Netherlands, 2013. [CrossRef]

24. Food and Agricultural Organization (FAO). State of the World's Forests 2016. Forests and Agriculture: Land Challenges and Opportunities; FAO: Rome, Italy, 2016. Available online: http:/ / www.fao.org/documents/card/en/c/ffed061b-82e0-4c74-af43-1a999a443 $\mathrm{fbf} /$ (accessed on 28 June 2021).

25. WWF-SA. Agriculture: Facts and Trends South Africa; WWF-SA: Cape Town, South Africa, 2010.

26. Gbetibouo, G.A.; Ringler, C. Mapping South African Farming Sector Vulnerability to Climate Change and Variability: A Subnational Assessment: Citeseer; IFPRI Discussion Paper 885; IFPRI: Washington, DC, USA, 2009.

27. Ndhlovu, M.P.; Mpofu, T. Communal farming, climate change adaptation and the media in Zimbabwe. Jàmbá 2016, 8. [CrossRef]

28. Department of Forest and Fisheries (DAFF). A Guide to the National Land Care Programme; DAFF: Pretoria, South Africa, 2002. Available online: https:/ / www.daff.gov.za/docs/Landcare/landsmall.htm (accessed on 26 June 2021).

29. Naidoo, K.D. The Practice, Constraints and Perceptions of Improving Soil Quality through Manure Application: A Case Study of Three Smallholder Farmer Groups. Ph.D. Thesis, University of KwaZulu-Natal, Pietermaritzburg, South Africa, March 2009. Available online: https: / researchspace.ukzn.ac.za/xmlui/bitstream/handle/10413/501/Naidoo_K_D_2009.pdf?sequence= 4\&isAllowed =y (accessed on 28 June 2021).

30. Food and Agricultural Organization (FAO). Impact of Climate Change: What FAO Is Doing to Assist the Country to Mitigate and Adapt; Department of Agriculture: Lewis Hove, South Africa, 2017; pp. 1-16.

31. Lipper, L.; Thornton, P.; Campbell, B.M.; Baedeker, T.; Braimoh, A.; Bwalya, M.; Caron, P.; Cattaneo, A.; Garrity, D.; Henry, K. Climate-smart agriculture for food security. Nat. Clim. Chang. 2014, 4, 1068-1072. [CrossRef]

32. Sejian, V.; Bhatta, R.; Malik, P.K.; Madiajagan, B.; Al-Hosni, Y.A.S.; Sullivan, M.; Gaughan, J.B. Livestock as sources of greenhouse gases and its significance to climate change. Greenh. Gases 2016, 11, 243-259.

33. Dlugokencky, E.J.; Steele, L.P.; Lang, P.M.; Masarie, K.A. The growth rate and distribution of atmospheric methane. J. Geophys. Res. Atmos. 1994, 99, 17021-17043. [CrossRef]

34. Moran, D.; Wall, E. Livestock production and greenhouse gas emissions: Defining the problem and specifying solutions. Anim. Front. 2011, 1, 19-25. [CrossRef]

35. Njeru, E.; Grey, S.; Kilawe, E.; FAO. Eastern Africa Climate-Smart Agriculture Scoping Study; FAO: Addis Ababa, Ethiopia, 2016.

36. Food, Agriculture and Natural Resources Policy Analysis Network (FANRPAN). A Comprehensive Scoping and Assessment Study of Climate Smart Agriculture Policies in South Africa; FANRPAN: Pretoria, South Africa, 2014. Available online: https://www.ccardesa. org/knowledge-products / comprehensive-scoping-and-assessment-study-climate-smart-agriculture-csa-policies (accessed on 7 April 2021).

37. Gaitán, L.; Läderach, P.; Graefe, S.; Rao, I.; Van der Hoek, R. Climate-smart livestock systems: An assessment of carbon stocks and GHG emissions in Nicaragua. PLoS ONE 2016, 11, e0167949. [CrossRef]

38. Habeeb, A.A.; Gad, A.E.; Atta, M.A. Temperature-humidity indices as indicators to heat stress of climatic conditions with relation to production and reproduction of farm animals. Int. J. Biotechnol. Recent Adv. 2018, 1, 35-50. [CrossRef]

39. Polsky, L.; von Keyserlingk, M.A. Invited review: Effects of heat stress on dairy cattle welfare. J. Dairy Sci. 2017, 100, 8645-8657. [CrossRef]

40. Cowley, F.; Barber, D.; Houlihan, A.; Poppi, D. Immediate and residual effects of heat stress and restricted intake on milk protein and casein composition and energy metabolism. J. Dairy Sci. 2015, 98, 2356-2368. [CrossRef] 
41. Department of Agriculture, Fisheries and Forestry (DAFF). South Africa Country Report on Farm Animal Genetic Resources; DAFF: Pretoria, South Aftica, 2006. Available online: http://www.fao.org/3/a1250e/annexes/CountryReports/SouthAfrica.pdf (accessed on 28 June 2021).

42. Kadzere, C. Environmentally smart animal agriculture and integrated advisory services ameliorate the negative effects of climate change on production. S. Afr. J. Anim. Sci. 2018, 48, 842-857. [CrossRef]

43. Singh, R.; Singh, G. Traditional agriculture: A climate-smart approach for sustainable food production. Energy Ecol. Environ. 2017, 2, 296-316. [CrossRef]

44. Mnkeni, P.; Mutengwa, C. Climate Smart Agriculture (CSA) Scoping Study: Case Study of South Africa; FANRPAN: Pretoria, South Africa, 2016; p. 31. Available online: https://www.ccardesa.org/knowledge-products/climate-smart-agriculture-csa-scopingstudy-case-study-south-africa (accessed on 28 June 2021).

45. Henry, B.; Charmley, E.; Eckard, R.; Gaughan, J.B.; Hegarty, R. Livestock production in a changing climate: Adaptation and mitigation research in Australia. Crop Pasture Sci. 2012, 63, 191-202. [CrossRef]

46. Nickerson, S. Management strategies to reduce heat stress, prevent mastitis and improve milk quality in dairy cows and heifers. UGA Ext. Bull. 2014, 1426, 1-10. Available online: https://secure.caes.uga.edu/extension/publications/files/pdf/B\%201426_1 .PDF (accessed on 28 June 2021).

47. Schulze, R.E. On Observations, Climate Challenges, the South African Agriculture Sector and Considerations for an Adaptation Handbook. In Handbook for Farmers, Officials and Other Stakeholders on Adaptation to Climate Change in the Agriculture Sector within South Africa. Section A: Agriculture and Climate Change in South Africa: Setting the Scene Chapter A1; Schulze, R.E., Ed.; AFF: Pretoria, South Africa, 2016. Available online: https:/ / www.nda.agric.za/doaDev/sideMenu/forestry/docs/Handbook\%20Part\%201.pdf (accessed on 28 June 2021).

48. Rosenstock, T.S.; Lamanna, C.; Namoi, N.; Arslan, A.; Richards, M. What Is the Evidence Base for Climate-Smart Agriculture in East and Southern Africa? A Systematic Map; Climate-Smart Agriculture Papers; Springer: Berlin/Heidelberg, Germany, 2018; pp. 141-151.

49. Agricultural Research Council (ARC). ARC Research Initiatives on Climate Variability and Climate Change; Agricultural Research Council: Pretoria, South Africa, 2020. Available online: https://static.pmg.org.za/200825ARC_Climate.pdf (accessed on 28 June 2021).

50. Amy. Back to Basics: Biological Use of Nutrients, in WI Beef Information Centre. University of Wisconsin-Madison. 2012. Available online: https:/ / fyi.extension.wisc.edu/wbic/2012/02/28/back-to-basics-biological-use-of-nutrients / (accessed on 5 April 2021).

51. Tharwat, M.; Al-Sobayil, F.; Ali, A.; Buczinski, S. Transabdominal ultrasonographic appearance of the gastrointestinal viscera of healthy camels (Camelus dromedaries). Res. Vet. Sci. 2012, 93, 1015-1020. [CrossRef] [PubMed]

52. Tapio, I.; Snelling, T.J.; Strozzi, F.; Wallace, R.J. The ruminal microbiome associated with methane emissions from ruminant livestock. J. Anim. Sci. Biotechnol. 2017, 8, 8. [CrossRef] [PubMed]

53. Stewart, R.D.; Auffret, M.D.; Warr, A.; Wiser, A.H.; Press, M.O.; Langford, K.W.; Liachko, I.; Snelling, T.J.; Dewhurst, R.J.; Walker, A.W. Assembly of 913 microbial genomes from metagenomic sequencing of the cow rumen. Nat. Commun. 2018, 9, 1-11.

54. Ulfina, G.; Lemma, F.; Tekalign, T.; Amanuel, B. Rumen manipulation: One of the promising strategies to improve livestock productivity-Review. J. Dairy. Vet. Sci. 2019, 9, 555758.

55. Torquati, B.; Venanzi, S.; Ciani, A.; Diotallevi, F.; Tamburi, V. Environmental sustainability and economic benefits of dairy farm biogas energy production: A case study in Umbria. Sustainability 2014, 6, 6696-6713. [CrossRef]

56. Getabalew, M.; Alemneh, T. The Application of Biotechnology on Livestock Feed Improvement. Arch. Biomed. Eng. Biotechnol. $2019,1,5$.

57. Kamra, D.N.; Agarwal, N.; Chaudhary, L.C.; Sahoo, A.; Pathak, N.N. Effect of feeding probiotic (Lactic acid producing bacteria) on the growth of coliform bacteria in the gastrointestinal tract of crossbred calves. In Proceedings of the VIII Animal Nutrition Research Worker's Conference, Chennai, India, 1997; pp. 130-131.

58. Santra, A.; Karim, S. Influence of ciliate protozoa on biochemical changes and hydrolytic enzyme profile in the rumen ecosystem. J. Appl. Microbiol. 2002, 92, 801-811. [CrossRef]

59. Hess, H.-D.; Beuret, R.; Lotscher, M.; Hindrichsen, I.; Machmuller, A.; Carulla, J.E.; Lascano, C.E.; Kreuzer, M. Ruminal fermentation, methanogenesis and nitrogen utilization of sheep receiving tropical grass hay-concentrate diets offered with Sapindus saponaria fruits and Cratylia argentea foliage. Anim. Sci. 2004, 79, 177-189. [CrossRef]

60. Patra, A.K. An overview of antimicrobial properties of different classes of phytochemicals. In Dietary Phytochemicals and Microbes; Springer: Berling/Heidelberg, Germany, 2012; pp. 1-32. [CrossRef]

61. Khatri-Chhetri, A.; Aryal, J.P.; Sapkota, T.B.; Khurana, R. Economic benefits of climate-smart agricultural practices to smallholder farmers in the Indo-Gangetic Plains of India. Curr. Sci. 2016, 110, 1251-1256.

62. Mthembu, N.N.; Zwane, E.M. The adaptive capacity of smallholder mixed-farming systems to the impact of climate change: The case of KwaZulu-Natal in South Africa. Jàmbá 2017, 9, 1-9. [CrossRef]

63. Lüscher, A.; Mueller-Harvey, I.; Soussana, J.-F.; Rees, R.; Peyraud, J.-L. Potential of legume-based grassland-livestock systems in Europe: A review. Grass Forage Sci. 2014, 69, 206-228. [CrossRef]

64. Garg, A.; Kankal, B.; Shukla, P. Methane emissions in India: Sub-regional and sectoral trends. Atmos. Environ. 2011, 45, 4922-4929. [CrossRef] 
65. Ayantunde, A.; Hiernaux, P.; Fernandez-Rivera, S.; Sangare, M. Nutrient Management in Livestock Systems in West Africa Sahel with Emphasis on Feed and Grazing Management. In Improving the Profitability, Sustainability and Efficiency of Nutrients Through Site Specific Fertilizer Recommendations in West Africa Agro-Ecosystems; Bationo, A., Ngaradoum, D., Youl, S., Lompo, F., Fening, J., Eds.; Springer: Cham, Switzerland, 2018.

66. International Centre for Tropical Agriculture (CIAT); Bureau for Food Security, United States Agency for International Development (BFS/USAID). Climate-Smart Agriculture in Uganda; CSA Country Profiles for Africa Series; International Centre for Tropical Agriculture (CIAT): Cali, Colombia; Bureau for Food Security, United States Agency for International Development (BFS/USAID): Washington, DC, USA, 2017; p. 22.

67. Cecilia, C.; Irang, M. The Importance of Proper Pasture Management. Agrimag. 2018. Available online: https://www.agriculture com.ph/2018/08/01/importance-of-proper-pasture-management/ (accessed on 10 October 2020).

68. Khanal, S.; Mandal, R.A. Assessing Effectiveness of Climate Smart Activities: A Study from Rural Areas, Nepal. Agric. Res. Technol. J. 2019, 20, 556125. [CrossRef]

69. Bezuidenhout, R. Veld Management Systems That Are Sustainable, in Farmers's Weekly. 2015. Available online: https://www. farmersweekly.co.za/agri-technology/farming-for-tomorrow/veld-management-systems/ (accessed on 2 April 2020).

70. Moyo, B.; Dube, S.; Lesoli, M.; Masika, P. Communal area grazing strategies: Institutions and traditional practices. Afr. J. Range Forage Sci. 2008, 25, 47-54. [CrossRef]

71. Danso-Abbeam, G.; Ehiakpor, D.S.; Aidoo, R. Agricultural extension and its effects on farm productivity and income: Insight from Northern Ghana. Agric. Food Secur. 2018, 7, 1-10. [CrossRef]

72. Maka, L.; Ighodaro, I.; Ngcobo-Ngotho, G. Capacity development for scaling up Climate-Smart Agriculture (CSA) innovations: Agricultural extension's role in mitigating climate change effects in Gqumashe community, Eastern Cape. S. Afri. J. Agric. Ext. 2019, 47, 45-53. [CrossRef]

73. Gwala, L.; Monde, N.; Muchenje, V. Qualitative data analysis of extension services for Nguni cattle project beneficiaries in Nkonkobe local municipality, South Africa. Int. J. Dev. Sustain. 2016, 5, 553-563.

74. Nyasimi, M.; Amwata, D.; Hove, L.; Kinyangi, J.; Wamukoya, G. Evidence of Impact: Climate-Smart Agriculture in Africa; CCAFS Working Paper No. 86; CGIAR Research Program on Climate Change, Agriculture and Food Security: Copenhagen, Denmark, 2014. Available online: www.ccafs.cgiar.org (accessed on 28 June 2021).

75. Miyanda, C. Climate Smart Practices: Conservation Agriculture in Southern Africa, Examples of Successful Project Implementation and Lessons Learnt, in Climate Smart Agriculture Conference Report. 2016. Available online: www.ccardesa.org-25_ReportClimate-Smart-Aug-2016_0.pdf (accessed on 12 February 2021).

76. Ngwira, A. How Climate Smart Is Conservation Agriculture: Examples from Malawi on Practices, Technologies and Constraints to Adoption; Centre for Coordination of Agricultural Research \& Development of Southern Africa (CCARDESA): Johannesburg, South Africa, 2016.

77. Zougmoré, R.; Partey, S.; Ouédraogo, M.; Omitoyin, B.; Thomas, T.; Ayantunde, A.; Ericksen, P.; Said, M.; Jalloh, A. Toward climate-smart agriculture in West Africa: A review of climate change impacts, adaptation strategies and policy developments for the livestock, fishery and crop production sectors. Agric. Food Secur. 2016, 5, 1-16. [CrossRef]

78. Ben, T.A. Content Analysis Reports on Climate Change Impacts, Vulnerability and Adaptation in Uganda; Citeseer: Princeton, NJ, USA, 2005.

79. Department of Environmental Affairs (DEA). The National Climate Change Response Policy. Department of Agriculture. Available online: http:/ / www.thedti.gov.za/parliament/DEA.pdf (accessed on 7 July 2020)2011.

80. SASAE. The Impact of Climate Change on Extension Delivery in South Africa; SASAE: Pretoria, South Africa, 2010 ; pp. 3-7.

81. Mphinyane, M.S.; Terblanché, S. Personal and socio-economical variables affecting the adoption of maize production intervention program by dryland farmers in the Vuwani district, Limpopo province. S. Afr. J. Agri. Ext. 2006, 35, $221-241$.

82. Kunene, N.; Fossey, A. A survey on livestock production in some traditional areas of Northern Kwazulu Natal in South Africa. Livest. Res. Rural Dev. 2006, 18, 30-33. Available online: http://lrrd.org/lrrd18/8/kune18113.htm (accessed on 10 November 2020).

83. Gwala, L. Effect of Agricultural Extension Services on Beneficiaries of the Nguni Cattle Project: The Case of Ncera and Kwezana Villages, Eastern Cape Province; University of Fort Hare: Alice, South Africa, 2013. Available online: http://hdl.handle.net/20.500.11837/391 (accessed on 10 January 2021).

84. Liebenberg, F. Agricultural Advisory Services in South Africa; Working Papers; Extension and Rural Development, Department of Agricultural Economics, University of Pretoria: Pretoria, South Africa, 2015. Available online: https://EconPapers.repec.org/ RePEc:ags:upaewp:241722 (accessed on 15 October 2020).

85. Dovie, D.B.; Shackleton, C.M.; Witkowski, E. Valuation of communal area livestock benefits, rural livelihoods and related policy issues. Land Use Policy 2006, 23, 260-271. [CrossRef]

86. Nwafor, C.; van der Westhuizen, C.; Ogundeji, A. Rural Smallholder Farmers' Awareness and Use of ICT-Based Market Information Sources in South Africa. Preprints 2020. [CrossRef]

87. Lekopanye, C.M.; Meenakshi, S. An Investigation on Information Communication Technology Awareness and Use in Improving Livestock Farming in Southern District, Botswana. Int. J. Adv. Comput. Sci. Appl. 2017, 8, 17-23.

88. Mthi, S.; Nyangiwe, N. Farmers perception on sheep production constraints in the communal grazing areas of the Eastern Cape Province, South Africa. Int. J. Prod. 2018, 9, 334-339. 
89. Mendelsohn, J. Farming Systems in Namibia; Research \& Information Services of Namibia (RAISON): Windhoek, Namibia, 2006 ; p. 80.

90. Makhura, M.; Kirsten, J.; Delgado, C. Transaction Costs and Smallholder Participation in the Maize Market in the Northern Province of South Africa; International Maize and Wheat Improvement Centre (CIMMYT): Mexico City, Mexico; Kenya Agricultural Research Institute (KARI): Nairobi, Kenya, 2002.

91. D'Haese, L.; Kirsten, J. Rural Development Focussing on Small Scale Agriculture in Southern Africa; Department of Agricultural Economics, Extension and Rural Development, University of Pretoria: Pretoria, South Africa, 2002.

92. Loevinsohn, M.; Sumberg, J.; Diagne, A.; Whitfield, S. Under What Circumstances and Conditions Does Adoption of Technology Result in Increased Agricultural Productivity? A Systematic Review; IDS: London, UK, 2013.

93. Viatte, G. Adopting Technologies for Sustainable Farming Systems: An OECD Perspective. In Adoption of Technologies for Sustainable Farming Systems Wageningen Workshop Proceedings; OECD: Paris, France, 2001; Volume 14, pp. 14-23.

94. FAO. Agriculture and Climate Change - Law and Governance in Support of Climate Smart Agriculture and International Climate Change Goals; FAO Legislative Studies No. 115; FAO: Rome, Italy, 2020. 